nephron

Practice
Nephron 2018;140:48-57

DOI: $10.1159 / 000490261$
Received: April 4, 2018

Accepted after revision: May 22, 2018

Published online: June 29, 2018

\title{
Rationale and Design of a Randomized Placebo-Controlled Clinical Trial Assessing the Renoprotective Effects of Potassium Supplementation in Chronic Kidney Disease
}

\author{
Martin Gritter ${ }^{\mathrm{a}}$ Liffert Vogt ${ }^{\mathrm{b}}$ Stanley M.H. Yeung ${ }^{\mathrm{c}}$ Rosa D. Wouda ${ }^{\mathrm{b}}$ \\ Christian R.B. Ramakers ${ }^{\mathrm{e}}$ Martin H. de Borst ${ }^{c}$ Joris I. Rotmans ${ }^{\mathrm{d}}$ \\ Ewout J. Hoorn ${ }^{\text {a }}$ \\ a Department of Internal Medicine, Division of Nephrology and Transplantation, Erasmus Medical Center, \\ Rotterdam, The Netherlands; ${ }^{b}$ Department of Internal Medicine, Division of Nephrology, Academic Medical Center, \\ Amsterdam, The Netherlands; ' ${ }^{\text {Department }}$ of Nephrology, University Medical Center Groningen, Groningen, \\ The Netherlands; ${ }^{d}$ Department of Internal Medicine, Nephrology, Leiden University Medical Center, Leiden, The \\ Netherlands; ${ }^{e}$ Department of Clinical Chemistry, Erasmus Medical Center, Rotterdam, The Netherlands
}

\section{Keywords}

Albuminuria · Alkali · Cardiovascular disease $\cdot$ Citrate . Hypertension

\begin{abstract}
Background/Aims: Dietary potassium $\left(\mathrm{K}^{+}\right)$has beneficial effects on blood pressure and cardiovascular (CV) outcomes. Recently, several epidemiological studies have revealed an association between urinary $\mathrm{K}^{+}$excretion (as proxy for dietary intake) and better renal outcomes in subjects with chronic kidney disease (CKD). To address causality, we designed the " $\mathrm{K}^{+}$in CKD" study. Methods: The $\mathrm{K}^{+}$in CKD study is a multicenter, randomized, double blind, placebo-controlled clinical trial aiming to include 399 patients with hypertension, CKD stage $3 \mathrm{~b}$ or 4 (estimated glomerular filtration rate [eGFR] $15-44 \mathrm{~mL} / \mathrm{min} / 1.73 \mathrm{~m}^{2}$ ), and an average eGFR decline $>2 \mathrm{~mL} / \mathrm{min} / 1.73 \mathrm{~m}^{2} /$ year. As safety measure, all included subjects will start with a 2-week open-label phase
\end{abstract}

of $40 \mathrm{mmol}$ potassium chloride daily. Patients who do not subsequently develop hyperkalemia (defined as serum $\mathrm{K}^{+}$ $>5.5 \mathrm{mmol} / \mathrm{L}$ ) will be randomized to receive potassium chloride, potassium citrate (both $\mathrm{K}^{+} 40 \mathrm{mmol} /$ day), or placebo for 2 years. The primary end point is the difference in eGFR after 2 years of treatment. Secondary end points include other renal outcomes ( $>30 \%$ decrease in eGFR, doubling of serum creatinine, end-stage renal disease, albuminuria), ambulatory blood pressure, CV events, all-cause mortality, and incidence of hyperkalemia. Several measurements will be performed to analyze the effects of potassium supplementation, including body composition monitoring, pulse wave velocity, plasma renin and aldosterone concentrations, urinary ammonium, and intracellular $\mathrm{K}^{+}$concentrations. Conclusion: The $\mathrm{K}^{+}$in CKD study will demonstrate if $\mathrm{K}^{+}$supplementation has a renoprotective effect in progressive CKD, and whether alkali therapy has additional beneficial effects.

(c) 2018 The Author(s)

Published by S. Karger AG, Basel

\begin{tabular}{ll}
\hline KARGER & $\begin{array}{l}\text { Ko 2018 The Author(s) } \\
\text { Published by S. Karger AG, Basel }\end{array}$ \\
Epenger & apcess \\
E-Mail karger@karger.com & This article is licensed under the Creative Commons Attribution- \\
www.karger.com/nef & $\begin{array}{l}\text { NonCommercial-NoDerivatives 4.0 International License (CC BY- } \\
\text { NC-ND) (http://www.karger.com/Services/OpenAccessLicense). } \\
\text { Usage and distribution for commercial purposes as well as any dis- } \\
\text { tribution of modified material requires written permission. }\end{array}$
\end{tabular}

Dr. Ewout J. Hoorn

Department of Internal Medicine

Division of Nephrology and Transplantation, Erasmus Medical Center

PO Box 2040, Room H-438, NL-3000 CA Rotterdam (The Netherlands)

E-Mail e.j.hoorn@erasmusmc.nl 


\section{Introduction}

From prehistoric times to the current age, our diet has changed from a high potassium-low sodium diet to a low potassium-high sodium diet [1]. So far public health efforts have largely focused on the high sodium component of our diet and on possible interventions to reduce it. Less emphasis has been placed on low $\mathrm{K}^{+}$intake, while there are good reasons to do so. For example, the beneficial effects of dietary $\mathrm{K}^{+}$on blood pressure and cardiovascular $(\mathrm{CV})$ outcomes are increasingly recognized experimentally and epidemiologically [2-7]. The recommendations by the World Health Organization, European Food Safety Authority, and U.S. Department of Health and Human Services to define dietary reference values for dietary $\mathrm{K}^{+}$ intake (90-120 $\mathrm{mmol} /$ day) are echoing this awareness [810]. Of interest, recent studies also suggest an effect of dietary $\mathrm{K}^{+}$on renal outcomes in patients with chronic kidney disease (CKD) [11-15]. That is, urinary $\mathrm{K}^{+}$excretion (as proxy for intake) was associated with slower progression of CKD in the majority of these studies (Table 1) [16]. Preliminary work in our own cohort confirmed this association in CKD patients [17].

Besides renoprotective effects, higher $\mathrm{K}^{+}$intake has also been associated with a lower risk of CV events $[2,11$, 18]. For example, the PURE-study (including $>100,000$ subjects worldwide) showed inverse relationships between urinary $\mathrm{K}^{+}$excretion, blood pressure, and CV outcomes $[6,7]$. A medium-sized clinical trial demonstrated that the use of $\mathrm{K}^{+}$-enriched salt reduced CV mortality in elderly men [19]. The beneficial effects of dietary $\mathrm{K}^{+} \mathrm{ob}-$ served in these epidemiological studies are supported by various physiological mechanisms. For example, dietary $\mathrm{K}^{+}$induces natriuresis by dephosphorylating the sodium chloride cotransporter, providing a novel mechanism for its anti-hypertensive effect $[20,21]$. In animals, dietary $\mathrm{K}^{+}$ also has protective effects in the vasculature and the kidney through inhibition of transforming growth factor $\beta$ and suppression of reactive oxygen species [22-25].

Our preliminary data also clearly indicate that patients with CKD generally have a low urinary $\mathrm{K}^{+}$excretion $(92.7 \%<90 \mathrm{mmol} /$ day, Fig. 1). Collectively, these data now pave the way for an intervention study to address causality and identify involved pathways [16, 26-28]. This should answer the question whether correcting the dietary $\mathrm{K}^{+}$deficit in patients with CKD may contribute to better renal and CV outcomes. Therefore, we hypothesize that $\mathrm{K}^{+}$supplementation in patients with CKD will slow the progression of CKD (Fig. 3). To address this hypothesis, we have designed a randomized clinical trial in pa- tients with CKD stages $3 \mathrm{~b}$ or 4 (estimated glomerular filtration rate $[\mathrm{eGFR}]$ range $15-44 \mathrm{~mL} / \mathrm{min} / 1.73 \mathrm{~m}^{2}$ ). Interestingly, in our preliminary data, $\mathrm{K}^{+}$excretion only showed a weak association with serum $\mathrm{K}^{+}$(Fig. 2), suggesting that $\mathrm{K}^{+}$intake is not the primary determinant of serum $\mathrm{K}^{+}$, and that $\mathrm{K}^{+}$supplementation in patients with $\mathrm{CKD}$ may be safe. However, hyperkalemia remains a dreaded complication in CKD and we acknowledge this safety concern [29]. Therefore, patients will start with a run-in phase of 2 weeks with potassium chloride to evaluate if hyperkalemia ensues. For patients included in the trial, a strict monitoring protocol analogous to the recent hyperkalemia trials testing the novel $\mathrm{K}^{+}$binders, will be adopted [30, 31].

Our research question will be linked to the recent evidence that alkali therapy also slows the progression of CKD $[32,33]$. To this end, the clinical trial will include 3 arms, namely, placebo, potassium chloride, and potassium citrate. The trial is powered for a relevant primary end point, namely, 2-year eGFR-decline (estimated by CKDEPI), and is planned to include 399 patients. Secondary end points will include ambulatory blood pressure, albuminuria, and CV parameters. In addition to 4 university medical centers, 16 affiliated hospitals will collaborate in patient recruitment. Together, we believe this intervention study will address a highly relevant question in the field of CKD progression and outcomes.

\section{Materials and Methods}

\section{Study Setting and Population}

The " $\mathrm{K}^{+}$in CKD" study is designed as a multicenter, doubleblind, randomized, placebo-controlled 3-arm trial in 399 participants with progressive CKD and hypertension. It will include adult patients ( $\geq 18$ years) with hypertension (office blood pressure $>$ 140/90 mm Hg or use of anti-hypertensive drugs), and CKD stage $3 \mathrm{~b}$ or $4\left(\mathrm{eGFR}\right.$ of $\left.15-44 \mathrm{~mL} / \mathrm{min} / 1.73 \mathrm{~m}^{2}\right)$ with evidence of progression in the preceding years $\left(>2 \mathrm{~mL} / \mathrm{min} / 1.73 \mathrm{~m}^{2}\right.$ in the preceding $\geq 1$ year with at least 3 measurements). Detailed patient inclusion and exclusion criteria are listed in Box 1. Patients will be recruited from the nephrology outpatient clinics of the 4 participating university medical centers (Amsterdam, Groningen, Leiden, and Rotterdam) and 16 affiliated hospitals (online suppl. Fig. S1; for all online suppl. material, see www.karger.com/ doi/10.1159/000490261).

\section{Study Design}

Individuals meeting the entry criteria will be enrolled in one of the 4 university medical centers. The planned recruitment period is 24 months. After informed consent is obtained and eligibility is assessed (Box 1), patients will start with the open-label run-in phase followed by the randomization phase. Figure 4 shows a schematic of the trial design. There will be 7 study visits (V0-V6) in which visits 


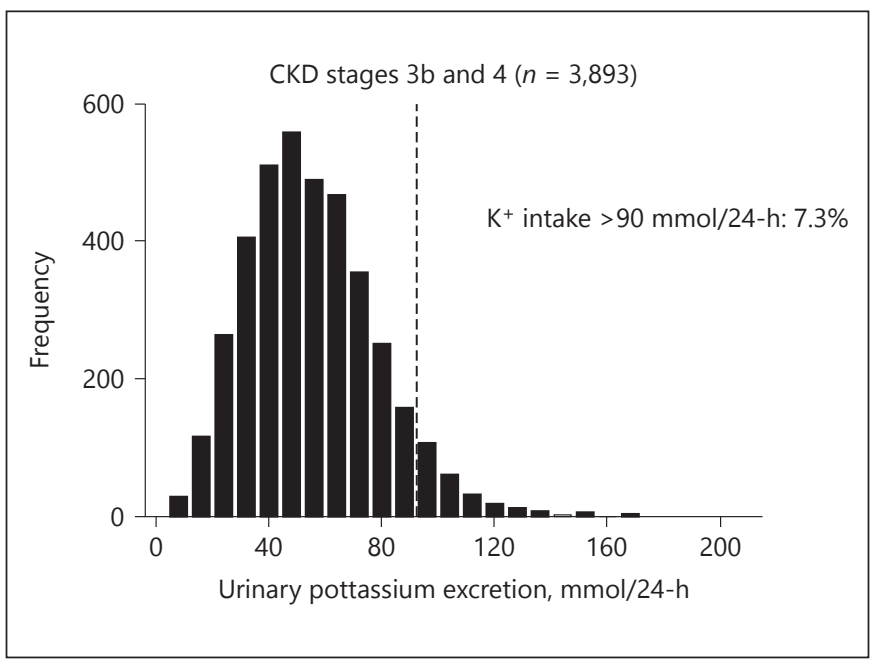

Fig. 1. Urinary $\mathrm{K}^{+}$excretion in patients with CKD. Preliminary work in our outpatient department showing the distribution of 24-h urinary $\mathrm{K}^{+}$excretion (as proxy for intake) in patients with CKD stages $3 \mathrm{~b}$ and 4 (estimated glomerular filtration rate of 15-44 $\mathrm{mL} / \mathrm{min} / 1.73 \mathrm{~m}^{2}$ ), indicating that the majority of patients $(92.7 \%)$ consumes less $\mathrm{K}^{+}$than recommended $(90 \mathrm{mmol} /$ day). CKD, chronic kidney disease; $\mathrm{K}^{+}$, potassium.

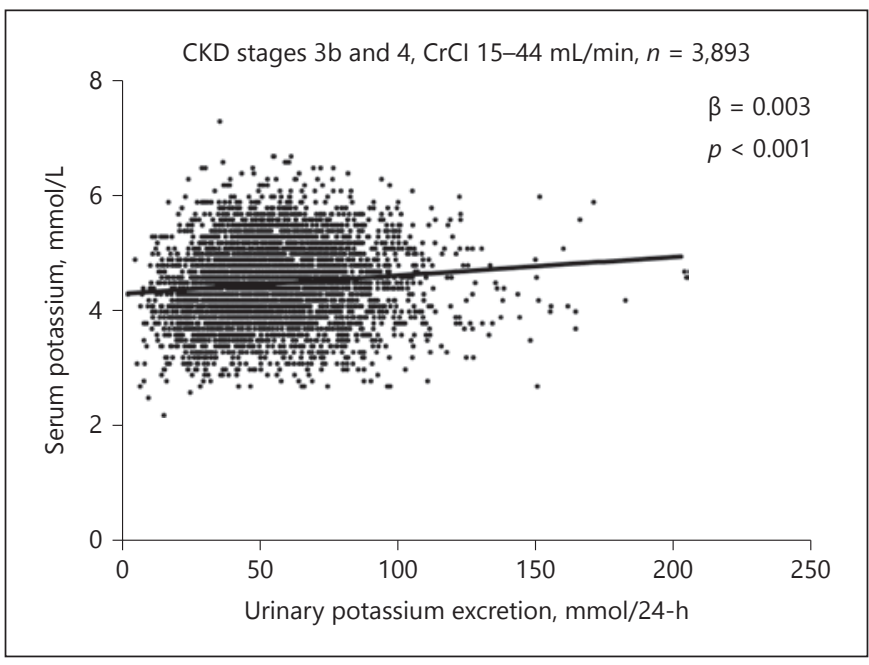

Fig. 2. Correlation between urinary $\mathrm{K}^{+}$excretion and serum $\mathrm{K}^{+}$ concentration. Preliminary data illustrating that in patients with CKD $3 \mathrm{~b}$ and 4 (eGFR of $15-44 \mathrm{~mL} / \mathrm{min} / 1.73 \mathrm{~m}^{2}$ ) urinary $\mathrm{K}^{+}$excretion (as proxy for intake) is only weakly correlated with the serum $\mathrm{K}^{+}$concentration. $\mathrm{CKD}$, chronic kidney disease; $\mathrm{CrCl}$, creatinine clearance; eGFR, estimated glomerular filtration rate.

Table 1. Summary of cohort studies analyzing the association between urinary potassium excretion and renal outcomes

\begin{tabular}{|c|c|c|c|c|c|c|}
\hline First author (cohort) & $n$ & $\begin{array}{l}\text { Primary } \\
\text { endpoint }\end{array}$ & $\begin{array}{l}\mathrm{eGFR}, \\
\mathrm{mL} / \mathrm{min} / \\
1.73 \mathrm{~m}^{2}\end{array}$ & $\begin{array}{l}\text { Median } \\
\text { follow-up }\end{array}$ & $\begin{array}{l}\text { Cut-offs for } \\
\text { urinary } \mathrm{K}^{+} \text {, } \\
\text { g/day }\end{array}$ & Main conclusion \\
\hline $\mathrm{He}$ [12] (CRIC) & 3,939 & $\begin{array}{l}50 \% \text { eGFR decline, } \\
\text { incident ESRD }\end{array}$ & $44 \pm 15$ & Not mentioned & 1.5 (ref.), 2.0, 2.6 & $\begin{array}{l}\text { Primary endpoint } \\
\text { higher in quartile } 4\end{array}$ \\
\hline $\begin{array}{l}\text { Kieneker [14] } \\
\text { (PREVEND) }\end{array}$ & 5,315 & $\begin{array}{l}\text { eGFR <60 or } \\
\text { albuminuria } \\
>30 \mathrm{mg} / \text { day }\end{array}$ & $97 \pm 6$ & 10.3 years & $\begin{array}{l}\text { Continuous } \\
\text { analysis }\end{array}$ & $\begin{array}{l}\text { Each 1-SD urinary } \mathrm{K}^{+} \\
\downarrow 16 \% \text { higher risk of } \\
\text { primary endpoint }\end{array}$ \\
\hline $\begin{array}{l}\text { Leonberg-Yoo [15] } \\
\text { (MDRD) }\end{array}$ & 812 & $\begin{array}{l}\text { RRT, all-cause } \\
\text { mortality }\end{array}$ & $32 \pm 12$ & 6.1 years & $\begin{array}{l}\text { Continuous } \\
\text { analysis }\end{array}$ & $\begin{array}{l}\text { Each } 1 \text {-SD } \uparrow \text { baseline } \\
\text { urinary } \mathrm{K}^{+} \text {adjusted } \\
\text { HR of } 0.83 \text { for } \\
\text { mortality }\end{array}$ \\
\hline
\end{tabular}

CV, cardiovascular; ESRD, end-stage renal disease; eGFR, estimated glomerular filtration rate; HR, hazard ratio; $\mathrm{K}^{+}$, potassium; ref., reference; MDRD, modification of diet in renal disease; RRT, renal replacement therapy. Conversion factor for units: $\mathrm{K}^{+}$in $\mathrm{g} / \mathrm{day}$ to $\mathrm{mmol} /$ day, $\times 25.6$. 
Fig. 3. Proposed pathways for the beneficial effects of $\mathrm{K}^{+}$supplementation in CKD. CV, cardiovascular; $\mathrm{CKD}$, chronic kidney disease; $\mathrm{K}^{+}$, potassium; $\mathrm{Na}^{+}$, sodium.

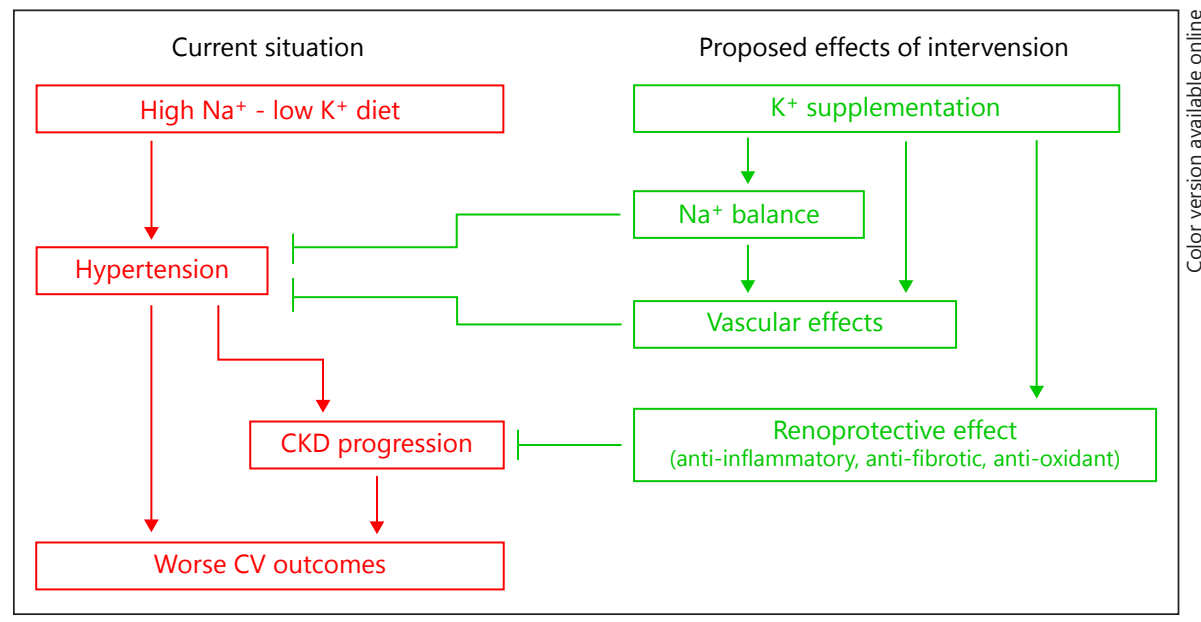

Box 1. Inclusion and exclusion criteria

Inclusion criteria

- Adults ( $\geq 18$ years)

- CKD stage $3 \mathrm{~b}$ or 4 (eGFR range $15-44 \mathrm{~mL} / \mathrm{min} / 1.73 \mathrm{~m}^{2}$ )

- $\Delta$ eGFR $>2 \mathrm{~mL} / \mathrm{min} / 1.73 \mathrm{~m}^{2} /$ year

- Hypertension

Exclusion criteria

- Hyperkalemia (serum $\mathrm{K}^{+}>5.5 \mathrm{mmol} / \mathrm{l}$ ) at study visit V0

- Medical reasons to continue dual RAAS-blockade, mineralocorticoid receptor blockers, potassium-sparing diuretics, or oral $\mathrm{K}^{+}$ binders

- Patients using calcineurin inhibitors

- Kidney transplant recipients

- Patients with an active gastro-intestinal ulcus

- Patients with previous history of ventricular cardiac arrhythmia

- Patients with a life expectancy $<6$ months

- Expected initiation of renal replacement therapy $<2$ years

- Incapacitated subjects or subjects who are deemed unfit to adequately adhere to instructions from the research team

- Women who are pregnant, breastfeeding or consider pregnancy in the coming 2 years

$\mathrm{CKD}$, chronic kidney disease; eGFR, estimated glomerular filtration rate; $\mathrm{K}^{+}$, potassium; RAAS, renin angiotensin aldosterone system.

V0 ( -2 weeks) and V1 (baseline) represent the start and end of the open-label phase, and visits V1-V6 the start and end of the randomized phase. The use of an angiotensin converting enzyme inhibitor (ACEi) or angiotensin receptor blocker (ARB) is allowed. In contrast to previous trials, we do not require maximum tolerated ACEi or ARB because we wanted to interfere as little as possible in the clinical management of the patients (study visits are independent of regular nephrology care). In addition, maximum-tolerated ACEi or $\mathrm{ARB}$ may have increased the risk for hyperkalemia and may have introduced a hemodynamic eGFR-decrease that would complicate the interpretation of the potassium effect on eGFR. In case the patient is using drugs listed in the exclusion criteria (e.g., spironolactone or dual renin angiotensin aldosterone system [RAAS]-blockade) but without a strict medical reason to continue this, this drug may be discontinued or switched, if the patient and the prescribing physician agree to do so. The actual stopping of the drug will take place after signing informed consent during the first study visit. This study visit will be labeled "Visit Stop Drug" (VSD) and will precede V0. This implies that, in this specific circumstance, patients will have 1 additional study visit (VSD) and that the complete study period will be 2 weeks longer. The total duration of the study will be 104 weeks ( +2 weeks in case of VSD). A randomization list using block randomization has been prepared by an independent statistician from the Department of Biostatistics, Erasmus Medical Center (randomization 1:1:1). The supplement manufacturer (see further) has printed the randomization numbers on the label of the containers with the study capsules. The randomization list with allocation is only known to the independent statistician, manufacturer, and the Pharmacy of the Erasmus Medical Center (which saves the list and is reachable $24 \mathrm{~h} /$ day for emergency unblinding). 


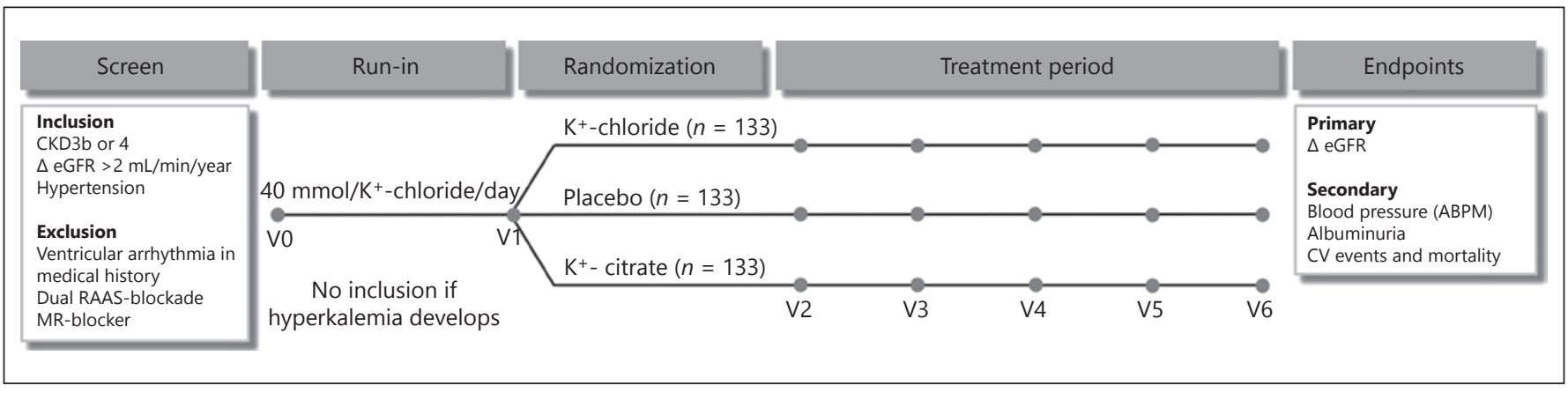

Fig. 4. Clinical trial design with main inclusion and exclusion criteria and primary and main secondary outcomes. ABPM, ambulatory blood pressure measurement; $\mathrm{CKD}$, chronic kidney disease; $\mathrm{CV}$, cardiovascular; eGFR, estimated glomerular filtration rate; $\mathrm{K}^{+}$-Chloride, potassium chloride; $\mathrm{K}^{+}$-Citrate, potassium citrate;

\section{Trial Treatments}

Investigational products (potassium chloride and potassium citrate) are classified as food supplement and listed as such on the European list of accepted food supplements. The active treatments provide $40 \mathrm{mmol}(1,564 \mathrm{mg}) \mathrm{K}^{+} /$day and either $40 \mathrm{mmol}(1,418$ $\mathrm{mg}) \mathrm{Cl}^{-}$/day or $13.3 \mathrm{mmol}(2,555 \mathrm{mg})$ citrate/day. This dose was selected because it represents the amount of $\mathrm{K}^{+}$necessary to increase the average dietary $\mathrm{K}^{+}$intake in patients with CKD (50 $\mathrm{mmol} /$ day) to the recommended minimum intake $(90 \mathrm{mmol} /$ day, Fig. 1). We acknowledge that true dietary $\mathrm{K}^{+}$intake may have been higher than $50 \mathrm{mmol} /$ day because of fecal $\mathrm{K}^{+}$excretion, which is increased in CKD $[26,34,35]$. However, even if this is true, dietary $\mathrm{K}^{+}$intake with supplementation is unlikely to exceed $120 \mathrm{mmol} /$ day, therefore falling within the recommended reference range [8$10]$. The study will use placebo as a comparator. The placebo consists mainly of starch. The capsules with potassium chloride, potassium citrate, and placebo will be produced specifically for this clinical trial by a large and accredited food supplement laboratory (Lab Medisan, Heerenveen, The Netherlands, www.lab-medisan.com) with previous experience in this type of supplementation studies [36]. All patients will receive an information card with direct contact information to the research team and instructions to contact the research team in the following 3 situations. The first situation is when they start any novel drug (prescription or over-the-counter) or find a need to use non-steroidal anti-inflammatory drugs. The reason to do so is that several commonly used drugs (e.g., cotrimoxazole, non-steroidal anti-inflammatory drugs) predispose to hyperkalemia, especially in patients using RAAS-blockers [37, 38]. The second situation is in the case of dose adjustments of prescribed drugs (e.g., RAAS-blockers), when the research team will decide whether this justifies earlier monitoring of serum $\mathrm{K}^{+}$ through an additional study visit. The third situation is in case of vomiting, diarrhea, or hospital admission, when we will temporarily discontinue the study supplements to prevent hyperkalemia.

\section{Standard Care}

Patients will maintain their regular diet and prescribed medications. Some of the patients with CKD will have been referred to a dietitian who may have started a low sodium and/or low $\mathrm{K}^{+}$diet. If
$\mathrm{MR}$, mineralocorticoid receptor; RAAS, renin angiotensin aldosterone system. V0, $\mathrm{t}=-2$ weeks; $\mathrm{V} 1, \mathrm{t}=0 ; \mathrm{V} 2, \mathrm{t}=1$ month; $\mathrm{V} 3$, $\mathrm{t}=6$ months; $\mathrm{V} 4, \mathrm{t}=12$ months; $\mathrm{V} 5, \mathrm{t}=18$ months; $\mathrm{V} 6, \mathrm{t}=24$ months.

so, patients may continue this as part of their standard care. We will record which patients have received such dietary recommendations. Patients will continue to be monitored by their own nephrologist. If possible, such visits may be combined with study visits.

\section{Primary and Secondary End Points}

The primary and secondary end points of the trial are shown in Box 2. The primary end point is the difference in eGFR (using the CKD-EPI creatinine equation) as measured at the end of the study (V6) and at baseline (V1). The secondary endpoints include a number of established renal and CV outcomes (Box 2). The eGFR slope was considered the primary end point but requires the assumptions that eGFR decline is constant and that the treatment effect does not depend on the rate of eGFR decline. We could not exclude the possibility that 1 or both of these assumptions would be violated.

\section{Data Collection and Measurements}

The measurements during the study visits are summarized in Table 2 and online supplementary Table S1. In addition to general CKD parameters, we will also measure intracellular $\mathrm{K}^{+}$in erythrocytes. Although one might expect a higher total body $\mathrm{K}^{+}$ in CKD, previous studies in CKD and dialysis patients showed $\mathrm{K}^{+}$ deficiency $[34,39]$. In case of hyperkalemia, an algorithm will be followed with explicit criteria when to perform an ECG, intensify monitoring, or discontinue supplements (online suppl. Fig. S2). A Clinical Data Management System will be used that meets the ICH-GCP and FDA 21 CFR part 11 criteria (Research Manager $^{\circledR}$, www.deresearchmanager.nl). Personal data will be handled in compliance with the Dutch Personal Data Protection Act. Data will be handled confidentially using a unique code. A subject identification code list will be used to link the data to the subject. The research team has access to the source data.

\section{Estimation of Power and Sample Size}

A power calculation was performed in collaboration with a statistician (Dr. M.A.J. de Ridder, Erasmus Medical Center). The study has 3 arms (placebo, potassium chloride, potassium citrate), and therefore 2 separate analyses for the primary end point will be per- 
Box 2. Primary and secondary endpoints

Primary end point

Difference in eGFR after 2 years of treatment

Secondary end points

Renal outcomes

$-\geq 30 \%$ decrease in eGFR

- eGFR slope analysis

- Doubling in serum creatinine or ESRD

- Progression to next CKD or albuminuria class

- Albuminuria

Cardiovascular outcomes

- Ambulatory blood pressure

- Volume and cardiovascular markers (pulse wave velocity, bioimpedance measures, NT-pro-BNP)

- Cardiovascular events (cardiovascular death*, non-fatal myocardial infarction, non-fatal stroke, unstable angina, resuscitated cardiac arrest)

Other outcomes

- All-cause mortality

- Incidence of hyperkalemia

* Coronary heart disease death, fatal myocardial infarction, fatal stroke and other CV death.

CKD, chronic kidney disease; eGFR, estimated glomerular filtration rate; ESRD, end-stage renal disease; NT-pro-BNP, N-terminal prohormone of the brain natriuretic peptide.

Table 2. Measurements

\begin{tabular}{|c|c|c|}
\hline Measurement & Category & Specification \\
\hline \multirow[t]{5}{*}{ Blood } & General CKD parameters & $\begin{array}{l}\text { Creatinine, } \mathrm{K}^{+} \text {, bicarbonate, urea, sodium, } \\
\text { calcium, phosphate, albumin, hemoglobin }\end{array}$ \\
\hline & CKD-MBD & $\begin{array}{l}\text { Parathyroid hormone, alkaline phosphatase, } \\
\text { FGF23 }\end{array}$ \\
\hline & Volume parameters & Renin, aldosterone, NT-pro-BNP \\
\hline & Intracellular $\mathrm{K}^{+}$ & Erythrocyte $\mathrm{K}^{+}$concentrations \\
\hline & Genetics & DNA-isolation for SNP-analysis \\
\hline \multirow[t]{3}{*}{ Urine (24-h and spot) } & $\begin{array}{l}\text { Kidney function and } \\
\text { nutrition status }\end{array}$ & Creatinine, urea, albuminuria \\
\hline & Electrolytes & Sodium, $\mathrm{K}^{+}$, calcium \\
\hline & Acid-base & Ammonia, citrate \\
\hline \multirow{3}{*}{$\begin{array}{l}\text { Cardiovascular and } \\
\text { volume parameters }\end{array}$} & $\mathrm{BP}$ & ABPM, office BP \\
\hline & Vascular stiffness & Pulse wave velocity \\
\hline & Body composition & Bioimpedance measurements \\
\hline
\end{tabular}

$\mathrm{ABPM}$, ambulatory BP measurement; $\mathrm{BP}$, blood pressure; $\mathrm{CKD}$, chronic kidney disease; CKD-MBD, chronic kidney disease - mineral and bone disorder; FGF 23, fibroblast growth factor 23; $\mathrm{K}^{+}$, potassium; NT-pro-BNP, $\mathrm{N}$-terminal prohormone of the brain natriuretic peptide; SNP, single nucleotide polymorphism. 
formed (placebo vs. potassium chloride and placebo vs. potassium citrate). To account for this multiple testing, $\alpha$ will be set at 0.025 . To assess the variability in the primary endpoint ( $\Delta$ eGFR in 2 years), we used a sample of real-life CKD patients from our own outpatient clinic that would be eligible for participation in this trial $(n=40)$. The standard deviation of $\Delta$ eGFR in this group of patients was 7.8 $\mathrm{mL} / \mathrm{min} / 1.73 \mathrm{~m}^{2}$. The expected effect of the interventions was based on a previous study in which sodium bicarbonate was also given for 2 years to reduce CKD progression. This study showed that this intervention resulted in a reduction of CKD progression of $4.05 \mathrm{~mL} /$ $\mathrm{min} / 1.73 \mathrm{~m}^{2}$ eGFR in 2 years [40]. For our sample size calculation, we used a slightly more conservative expected effect of $3 \mathrm{~mL} /$ $\mathrm{min} / 1.73 \mathrm{~m}^{2}$ in 2 years. These variables were entered in a sample size calculator and indicated that 260 patients would be required. Therefore, for our study with 3 arms, this would result in 390 patients. We decided to aim for a slightly higher number of randomized patients, namely, 399 patients. The flowchart with the anticipated patient numbers, including anticipated drop-out and withdrawal rates, is shown in online supplementary Figure S3.

\section{Statistical Analysis}

The primary hypothesis test will be the difference between placebo and treatment groups after 2 years. The primary analysis will be an intention-to-treat analysis of the primary end point $(\Delta$ eGFR) in $\mathrm{K}^{+}$supplementation (potassium chloride or potassium citrate) vs. placebo.

The secondary analysis will be a per-protocol analysis of the primary endpoint $(\Delta \mathrm{eGFR})$ in either of the $\mathrm{K}^{+}$supplementation arms vs. placebo.

\section{Ethical Considerations}

The Medical Ethics Committee of the Erasmus Medical Center approved the protocol and informed consent form (METC-2017226). The study will be conducted according to the principles of the Declaration of Helsinki (version 2013) and in accordance with the Medical Research Involving Human Subjects Act. All participants have the right to withdraw at any time during the study. Further, stopping rules for patients and the trial are provided in online supplementary Table S2.

The study is registered at www.ClinicalTrials.gov (study number: NCT03253172).

\section{Study Organization}

A steering committee oversaw the design and will overview the conduct of the study. An independent data safety monitoring board has been established to monitor the safety of the trial and can advise to stop the study based on serious adverse events and/ or interim analysis of adverse effects (online suppl. Table S2). This data safety monitoring board will perform its analyses after inclusion of $10 \%$ of the patients and half-yearly for the duration of the study. An independent monitor will evaluate the study progress and quality and completeness of study data 2 times per year.

\section{Discussion}

The $\mathrm{K}^{+}$in CKD study seeks to determine whether $\mathrm{K}^{+}$ supplementation attenuates $\mathrm{CKD}$ progression.
The association between dietary $\mathrm{K}^{+}$intake, blood pressure, and outcomes has primarily been investigated in non-CKD populations. The relationship between $\mathrm{K}^{+}$ and blood pressure in the INTERSALT, PURE, and NHANES studies persisted after adjusting for confounding variables $[6,41,42]$. The DASH-trial was an intervention study and showed that with constant sodium intake, an increase in dietary $\mathrm{K}^{+}$reduced blood pressure [43]. Subjects with hypertension were even more sensitive to the DASH-diet and responded with a threefold greater reduction in blood pressure. In a follow-up study, the anti-hypertensive effect of dietary $\mathrm{K}^{+}$ was found to be greater when sodium intake was higher [44]. Although in the DASH-study the link between blood pressure and $\mathrm{K}^{+}$could clearly be established by analysis of 24-h urines, other elements of the DASHdiet may have contributed to the response. In this regard, it is important to analyze studies in which the only intervention was $\mathrm{K}^{+}$supplementation. A metaanalysis, which included 22 randomized clinical trials, more conclusively dissected the effects of dietary interventions on blood pressure, pinpointing it to a direct effect of $\mathrm{K}^{+}[2]$. The PURE study also explored the association between urinary $\mathrm{K}^{+}$excretion and CV outcomes [7]. Compared to a urinary $\mathrm{K}^{+}$excretion $<1.5 \mathrm{~g} /$ day, higher urinary $\mathrm{K}^{+}$excretion was associated with a lower risk of death or $\mathrm{CV}$ events. Although causality cannot be inferred from this epidemiological study, it is of interest to note that this association remained after correction for physical activity, dietary factors (including caloric intake and sodium content), and blood pressure [7]. In addition to $\mathrm{K}^{+}$s effect on blood pressure, the meta-analysis also showed a $24 \%$ reduction of incident stroke [2]. The experimental literature corroborates the notion that the $\mathrm{CV}$ protection of $\mathrm{K}^{+}$primarily concerns a reduced risk of stroke $[18,45]$. Of interest, this protective effect was independent of blood pressure and suggests a direct effect of $\mathrm{K}^{+}$on endothelial cells. For example, He et al. [3] performed a placebo-controlled cross-over trial comparing potassium chloride with potassium bicarbonate in 42 pre-hypertensive individuals. Although the effects on blood pressure were modest (possibly because these individuals consumed a relatively low sodium-high $\mathrm{K}^{+}$diet), the effects on $\mathrm{CV}$ parameters were striking. Both potassium chloride and potassium bicarbonate significantly improved endothelial function, increased arterial compliance, decreased left ventricular mass, and improved left ventricular diastolic function. A Taiwanese study randomized a veteran retirement home to prepare 
meals with $\mathrm{K}^{+}$-enriched salt or with sodium chloride in 1,981 veterans [19]. Using this approach, the number of $\mathrm{CV}$ deaths nearly halved in the experimental group after a median follow-up of 2.5 years.

Given the salt sensitivity of patients with CKD and their high $\mathrm{CV}$ burden, $\mathrm{K}^{+}$supplementation may be especially effective in this multimorbid patient population. This hypothesis has recently been addressed in 6 large CKD cohorts (Table 1) [11-16]. Smyth et al. [13] performed their analysis in the ONTARGET and TRANSCEND cohorts. They found that higher 24-h urinary $\mathrm{K}^{+}$(but not sodium) was associated with a lower risk of renal outcomes ( $\geq 30 \%$ eGFR-decline or dialysis) [13]. Of interest, higher urinary $\mathrm{K}^{+}$excretion was not associated with a higher incidence of hyperkalemia. This suggests that dietary intake is not the primary determinant of serum $\mathrm{K}^{+}$in CKD and adds to the safety of our proposed $\mathrm{K}^{+}$supplementation trial. Araki et al. [11] analyzed the association between 24 -h urinary $\mathrm{K}^{+}$excretion, renal outcomes, and CV events in Japanese patients with type 2 diabetes. During a median follow-up of 11 years, patients in the highest quartile of urinary $\mathrm{K}^{+}$excretion (>2.9 g/day) had significantly fewer CV events, 50\% reduction in eGFR, or start of renal replacement therapy than patients in the lowest quartile $(<1.72 \mathrm{~g} /$ day $)$. Furthermore, patients in the highest quartile showed less annual eGFR-decline (-1.3 vs. $-2.2 \mathrm{~mL} \mathrm{~min} / 1.73 \mathrm{~m}^{2}$ ). Kieneker et al. [14] studied the association between urinary $\mathrm{K}^{+}$excretion (using two 24-h urine samples) and CKD in the PREVEND cohort (general population enriched for subjects with albuminuria). CKD was defined as de novo development of an eGFR $<60 \mathrm{~mL} /$ $\mathrm{min} / 1.73 \mathrm{~m}^{2}$ and/or albuminuria $>30 \mathrm{mg} /$ day. Each standard deviation decrement in urinary $\mathrm{K}^{+}$excretion $(21 \mathrm{mmol} /$ day) was independently associated with a $16 \%$ higher risk of developing CKD. We performed a similar analysis in adult outpatients with long-term follow-up (median 12.7 years), which again showed that higher $\mathrm{K}^{+}$ intake ( $>80 \mathrm{mmol} /$ day) was associated with a lower risk of a $60 \%$ eGFR decline and RRT [17]. The study by $\mathrm{He}$ et al. [12] was conducted in the CRIC-cohort and analyzed the association between three 24 -h urinary $\mathrm{K}^{+}$excretions, halving of eGFR, and incident end-stage renal disease. In contrast with the other studies, this study found a higher risk of eGFR-decline and end-stage renal disease in the highest quartile of urinary $\mathrm{K}^{+}$excretion. Finally, Leonberg-Yoo et al. [15] studied the association between time-updated average urinary $\mathrm{K}^{+}$excretion, kidney failure, and all-cause mortality in a post hoc analysis of the Modification of Diet in Renal Disease
Study. Higher urinary $\mathrm{K}^{+}$excretion was not associated with kidney failure; however, each standard deviation increase in urinary $\mathrm{K}^{+}(23 \mathrm{mmol} /$ day $)$ was associated with a $17 \%$ lower all-cause mortality rate in fully adjusted models.

The effect of $\mathrm{K}^{+}$supplementation may be modulated by the accompanying anion. The anions chloride, bicarbonate, and citrate have different metabolic pathways and are handled by different kidney transport mechanisms. Furthermore, alkali therapy may help to correct chronic metabolic acidosis of CKD. In fact, sodium bicarbonate supplementation was shown to slow the progression of CKD [40]. Recent data indicate that low ammonium excretion (which will also be measured in our trial) is associated with death and kidney failure in patients with CKD and hypertension, even among those without acidosis [46]. This raises the question whether potassium bicarbonate or potassium citrate may have an additive effect on slowing CKD progression. Although both bicarbonate and citrate correct chronic metabolic acidosis of CKD, hypocitraturia in CKD is common and may occur independently of acidosis [47]. This provides the rationale to include both a potassium chloride and potassium citrate intervention in our clinical trial.

Our study has a number of limitations. First, all participants are requested to consume $6(3 \times 2)$ capsules/ day for 2 years on top of their prescribed medication, which will increase pill burden. Although higher $\mathrm{K}^{+}$intake could also be achieved by changes in diet [48], this would not address the specific effect of $\mathrm{K}^{+}$. During the design of the trial we also performed a survey among the patient panel of the Dutch Kidney Patient Society which indicated they would prefer a capsule or tablet rather than a liquid formulation. In addition, because $\mathrm{K}^{+}$has a specific taste, it would be difficult to design a placebo for the liquid formulation. The reason to select capsules instead of tablets is that they are easier to swallow and easier to produce for the desired dosage. Second, there could be a trial effect in the sense that all participants may increase dietary $\mathrm{K}^{+}$intake. This could attenuate the negative effects of a low $\mathrm{K}^{+}$diet in the placebo group and therefore suppress the overall effect of $\mathrm{K}^{+}$supplementation. However, because our supplementation will increase dietary $\mathrm{K}^{+}$intake to the recommended minimal intake, we think this diluting effect will be limited. Finally, we decided to estimate rather than to measure GFR because measuring GFR in such a large sample size would be logistically challenging. In addition, measured GFR may have more variation than eGFR, introducing 
a larger error when using differences between 2 timepoints [49].

In conclusion, to our knowledge, the $\mathrm{K}^{+}$in CKD study is the first clinical trial that will investigate the efficacy of $\mathrm{K}^{+}$supplementation on attenuation of kidney function decline in CKD.

\section{Acknowledgements}

The authors thank Dr. M.A.J. de Ridder for help with the power calculation.

\section{Ethics Statement}

The $\mathrm{K}^{+}$in CKD study has been approved by the Medical Ethics Committee of the Erasmus Medical Center and all participating subjects are required to give informed consent.

\section{Disclosure Statement}

The authors declare that they have no conflicts of interest to disclose.

\section{Funding Source}

This study is funded by a Consortium Grant from the Dutch Kidney Foundation (CP1601). The funding party does not have any role in the development and progress of the study, nor in the publication process.

\section{Author Contributions}

Research idea and study design: L.V., M.H.B., J.I.R., and E.J.H.; data acquisition: M.G., S.M.H.Y., R.D.W., C.R.B.R., and M.H.B.; supervision or mentorship: L.V., M.H.B., J.I.R., and E.J.H. All authors read and approved the final manuscript.

\section{References}

1 Eaton SB, Eaton SB 3rd, Konner MJ: Paleolithic nutrition revisited: A twelve-year retrospective on its nature and implications. Eur J Clin Nutr 1997;51:207-216.

2 Aburto NJ, Hanson S, Gutierrez H, Hooper L, Elliott P, Cappuccio FP: Effect of increased potassium intake on cardiovascular risk factors and disease: Systematic review and metaanalyses. BMJ 2013;346:f1378

3 He FJ, Marciniak M, Carney C, Markan$\mathrm{du}$ ND, Anand V, Fraser WD, Dalton RN, Kaski JC, MacGregor GA: Effects of potassium chloride and potassium bicarbonate on endothelial function, cardiovascular risk factors, and bone turnover in mild hypertensives. Hypertension 2010;55:681688.

4 He FJ, Markandu ND, Coltart R, Barron J, MacGregor GA: Effect of short-term supplementation of potassium chloride and potassium citrate on blood pressure in hypertensives. Hypertension 2005;45:571-574.

5 Meneely GR, Ball CO: Experimental epidemiology of chronic sodium chloride toxicity and the protective effect of potassium chloride. Am J Med 1958;25:713-725.

6 Mente A, O’Donnell MJ, Rangarajan S, McQueen MJ, Poirier P, Wielgosz A, Morrison H, Li W, Wang X, Di C, Mony P, Devanath A, Rosengren A, Oguz A, Zatonska K, Yusufali AH, Lopez-Jaramillo P, Avezum A, Ismail N, Lanas F, Puoane T, Diaz R, Kelishadi R, Iqbal R, Yusuf R, Chifamba J, Khatib R, Teo K, Yusuf S; PURE Investigators: Association of urinary sodium and potassium excretion with blood pressure. N Engl J Med 2014;371:601611.
7 O’Donnell M, Mente A, Rangarajan S, McQueen MJ, Wang X, Liu L, Yan H, Lee SF, Mony P, Devanath A, Rosengren A, LopezJaramillo P, Diaz R, Avezum A, Lanas F, Yusoff K, Iqbal R, Ilow R, Mohammadifard N, Gulec S, Yusufali AH, Kruger L, Yusuf R, Chifamba J, Kabali C, Dagenais G, Lear SA, Teo $\mathrm{K}$, Yusuf S; PURE Investigators: Urinary sodium and potassium excretion, mortality, and cardiovascular events. N Engl J Med 2014; 371:612-623.

8 WHO. Guideline: Potassium intake for adults and children. Geneva, World Health Organization (WHO), 2012

9 EFSA NDA Panel (EFSA Panel on Dietetic Products, Nutrition and Allergies), Turck D, Bresson J-L, Burlingame B, Dean T, Fairweather-Tait S, Heinonen M, Hirsch-Ernst KI, Mangelsdorf I, McArdle H, NeuhäuserBerthold M, Nowicka G, Pentieva K, Sanz Y, Siani A, Sjödin A, Stern M, Tomé D, Van Loveren $\mathrm{H}$, Vinceti M, Willatts $\mathrm{P}$, Aggett $\mathrm{P}$, Martin A, Przyrembel H, Brönstrup A, Ciok J, Gómez Ruiz JÁ, de Sesmaisons-Lecarré A, Naska A: Scientific opinion on dietary reference values for potassium. EFSA J 2016;14(10):4592, 56 pp., DOI: 10.2903/j. efsa.2016.4592.

10 U.S. Department of Health and Human Services and U.S. Department of Agriculture. 2015-2020 Dietary Guidelines for Americans. 8th Edition. December 2015. Available at https://health.gov/dietaryguidelines/2015/ guidelines/.

11 Araki S, Haneda M, Koya D, Kondo K, Tanaka S, Arima H, Kume S, Nakazawa J, ChinKanasaki M, Ugi S, Kawai H, Araki H, Uzu T,
Maegawa $\mathrm{H}$ : Urinary potassium excretion and renal and cardiovascular complications in patients with type 2 diabetes and normal renal function. Clin J Am Soc Nephrol 2015; 10:2152-2158.

12 He J, Mills KT, Appel LJ, Yang W, Chen J, Lee BT, Rosas SE, Porter A, Makos G, Weir MR, Hamm LL, Kusek JW; Chronic Renal Insufficiency Cohort Study Investigators: Urinary sodium and potassium excretion and CKD progression. J Am Soc Nephrol 2016;27: 1202-1212.

13 Smyth A, Dunkler D, Gao P, Teo KK, Yusuf S, O'Donnell MJ, Mann JF, Clase CM, ONTARGET and TRANSCEND investigators: The relationship between estimated sodium and potassium excretion and subsequent renal outcomes. Kidney Int 2014;86:1205-1212.

14 Kieneker LM, Bakker SJ, de Boer RA, Navis GJ, Gansevoort RT, Joosten MM: Low potassium excretion but not high sodium excretion is associated with increased risk of developing chronic kidney disease. Kidney Int 2016;90: 888-896.

15 Leonberg-Yoo AK, Tighiouart H, Levey AS Beck GJ, Sarnak MJ: Urine potassium excretion, kidney failure, and mortality in CKD. Am J Kidney Dis 2017;69:341-349.

16 Hoorn EJ, Vogt L, Rotmans JI: Nutritional management of chronic kidney disease. $\mathrm{N}$ Engl J Med 2018;378:583-584.

17 Van Noordenne N, Olde Engberink RHG, Van den Hoek TC, Van den Born BH, Vogt L: Associations of 15 -year average potassium intake with long-term cardiovascular and renal outcome in the outpatient setting. J Hypertension 2016;34:e421. 
18 Tobian L, Lange J, Ulm K, Wold L, Iwai J: Potassium reduces cerebral hemorrhage and death rate in hypertensive rats, even when blood pressure is not lowered. Hypertension 1985; 7:I110-114.

19 Chang HY, Hu YW, Yue CS, Wen YW, Yeh WT, Hsu LS, Tsai SY, Pan WH: Effect of potassium-enriched salt on cardiovascular mortality and medical expenses of elderly men. Am J Clin Nutr 2006;83:1289-1296.

20 Sorensen MV, Grossmann S, Roesinger M, Gresko N, Todkar AP, Barmettler G, Ziegler $\mathrm{U}$, Odermatt A, Loffing-Cueni D, Loffing J: Rapid dephosphorylation of the renal sodium chloride cotransporter in response to oral potassium intake in mice. Kidney Int 2013;83: 811-824.

21 van der Lubbe N, Moes $A D$, Rosenbaek LL, Schoep S, Meima ME, Danser AH, Fenton $\mathrm{RA}$, Zietse R, Hoorn EJ: $\mathrm{K}^{+}$-induced natriuresis is preserved during $\mathrm{Na}^{+}$depletion and accompanied by inhibition of the $\mathrm{Na}^{+}-\mathrm{Cl}^{-}$cotransporter. Am J Physiol Renal Physiol 2013; 305:F1177-1188.

22 Kido M, Ando K, Onozato ML, Tojo A, Yoshikawa M, Ogita T, Fujita T: Protective effect of dietary potassium against vascular injury in salt-sensitive hypertension. Hypertension 2008;51:225-231.

23 Sun Y, Byon $\mathrm{CH}$, Yang Y, Bradley WE, Dell'Italia LJ, Sanders PW, Agarwal A, Wu H, Chen Y: Dietary potassium regulates vascular calcification and arterial stiffness. JCI Insight 2017;2:pii:94920.

24 Wang W, Soltero L, Zhang P, Huang XR, Lan $\mathrm{HY}$, Adrogue HJ: Renal inflammation is modulated by potassium in chronic kidney disease: Possible role of Smad7. Am J Physiol Renal Physiol 2007;293:F1123-F1130.

25 Ying WZ, Aaron K, Wang PX, Sanders PW Potassium inhibits dietary salt-induced transforming growth factor-beta production. Hypertension 2009;54:1159-1163.

26 Kovesdy CP, Appel LJ, Grams ME, Gutekunst L, McCullough PA, Palmer BF, Pitt B, Sica DA, Townsend RR: Potassium homeostasis in health and disease: A scientific workshop cosponsored by the national kidney foundation and the american society of hypertension. Am J Kidney Dis 2017;70:844-858.

27 Elbehary S, Szerlip HM, McCullough PA: Potassium excretion and outcomes in CKD: is K intake OK? Am J Kidney Dis 2017;69:325327.

28 Palmer BF, Clegg DJ: Achieving the benefits of a high-potassium, paleolithic diet, without the toxicity. Mayo Clin Proc 2016;91:496508.

29 Burnier M: Should we eat more potassium to better control blood pressure in hypertension? Nephrol Dial Transplant 2018, Epub ahead of print.

30 Weir MR, Bakris GL, Bushinsky DA, Mayo MR, Garza D, Stasiv Y, Wittes J, ChristSchmidt H, Berman L, Pitt B, Investigators $\mathrm{OH}$ : Patiromer in patients with kidney disease and hyperkalemia receiving RAAS inhibitors. N Engl J Med 2015;372:211-221.

31 Packham DK, Rasmussen HS, Lavin PT, ElShahawy MA, Roger SD, Block G, Qunibi W, Pergola P, Singh B: Sodium zirconium cyclosilicate in hyperkalemia. N Engl J Med 2015; 372:222-231.

32 Raphael KL: Approach to the treatment of chronic metabolic acidosis in CKD. Am J Kidney Dis 2016;67:696-702.

33 de-Brito Ashurst I, O’Lone E, Kaushik T, McCafferty K, Yaqoob MM: Acidosis: Progression of chronic kidney disease and quality of life. Pediatr Nephrol 2015;30:873-879.

34 van Ypersele de Strihou C: Potassium homeostasis in renal failure. Kidney Int 1977;11: 491-504.

35 Sorensen MV, Matos JE, Praetorius HA, Leipziger J: Colonic potassium handling. Pflugers Arch 2010;459:645-656.

36 Joris PJ, Plat J, Bakker SJ, Mensink RP: Longterm magnesium supplementation improves arterial stiffness in overweight and obese adults: results of a randomized, double-blind, placebo-controlled intervention trial. Am JClin Nutr 2016;103:1260-1266.

37 Antoniou T, Gomes T, Juurlink DN, Loutfy MR, Glazier RH, Mamdani MM: Trimethoprim-sulfamethoxazole-induced hyperkalemia in patients receiving inhibitors of the renin-angiotensin system: a populationbased study. Arch Intern Med 2010;170: 1045-1049.

38 Fournier JP, Lapeyre-Mestre M, Sommet A, Dupouy J, Poutrain JC, Montastruc JL: Laboratory monitoring of patients treated with antihypertensive drugs and newly exposed to non steroidal anti-inflammatory drugs: a cohort study. PLoS One 2012;7:e34187.

39 Dolson GM, Ellis KJ, Johnson ML, Adrogue $\mathrm{HJ}$ : Incidence and consequences of total body potassium depletion in chronic hemodialysis patients. Front Biosci 2003;8:a126132.

40 de Brito-Ashurst I, Varagunam M, Raftery MJ, Yaqoob MM: Bicarbonate supplementa- tion slows progression of $\mathrm{CKD}$ and improves nutritional status. J Am Soc Nephrol 2009;20: 2075-2084.

41 Intersalt: An international study of electrolyte excretion and blood pressure. Results for 24 hour urinary sodium and potassium excretion. Intersalt cooperative research group. BMJ 1988;297:319-328.

42 Jackson SL, Cogswell ME, Zhao L, Terry AL, Wang CY, Wright J, Coleman King SM, Bowman B, Chen TC, Merritt RK, Loria CM: Association between urinary sodium and potassium excretion and blood pressure among adults in the united states: National health and nutrition examination survey, 2014. Circulation 2018;137:237-246.

43 Appel LJ, Moore TJ, Obarzanek E, Vollmer WM, Svetkey LP, Sacks FM, Bray GA, Vogt TM, Cutler JA, Windhauser MM, Lin $\mathrm{PH}$, Karanja N: A clinical trial of the effects of dietary patterns on blood pressure. DASH collaborative research group. N Engl J Med 1997; 336:1117-1124.

44 Sacks FM, Svetkey LP, Vollmer WM, Appel LJ, Bray GA, Harsha D, Obarzanek E, Conlin PR, Miller ER 3rd, Simons-Morton DG, Karanja N, Lin PH; DASH-Sodium Collaborative Research Group: Effects on blood pressure of reduced dietary sodium and the dietary approaches to stop hypertension (DASH) diet. DASH-sodium collaborative research group. N Engl J Med 2001;344:3-10.

45 Sugimoto T, Tobian L, Ganguli MC: High potassium diets protect against dysfunction of endothelial cells in stroke-prone spontaneously hypertensive rats. Hypertension 1988; 11:579-585.

46 Raphael KL, Carroll DJ, Murray J, Greene T, Beddhu S: Urine ammonium predicts clinical outcomes in hypertensive kidney disease. J Am Soc Nephrol 2017;28:2483-2490.

47 Zacchia M, Preisig P: Low urinary citrate: an overview. J Nephrol 2010;23(suppl 16):S49S56.

48 Goraya N, Simoni J, Jo CH, Wesson DE: A comparison of treating metabolic acidosis in CKD stage 4 hypertensive kidney disease withruits and vegetables or sodium bicarbonate. Clin J Am Soc Nephrol 2013;8:371381

$49 \mathrm{Ku}$ E, Xie D, Shlipak M, Hyre Anderson A, Chen J, Go AS, He J, Horwitz EJ, Rahman M, Ricardo AC, Sondheimer JH, Townsend RR, Hsu CY, Investigators CS: Change in measured GFR versus eGFR and CKD outcomes. J Am Soc Nephrol 2016;27:2196-2204. 